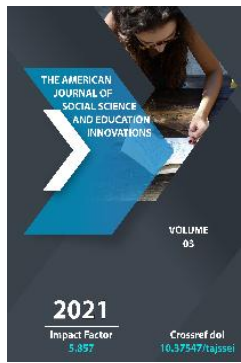

\title{
Enhancing Creativity In The Process Of Developing Students' Speech
}

\author{
Ziyaqulova Maftuna Shuhrat Qizi \\ Student Of The Faculty Of Pedagogy, Termez State University, Termez, Uzbekistan
}

Journal Website:

http://theamericanjour

nals.com/index.php/taj

ssei

Copyright: Original content from this work may be used under the terms of the creative commons attributes 4.0 licence.

\section{ABSTRACT}

For the comprehensive intellectual, moral, aesthetic and physical development of children, it is important to apply creative ideas to society, taking into account the best foreign practices. This article describes the methods and techniques to increase creativity in the process of developing children's speech.

\section{KEYWORDS}

Speech, speech culture, pronunciation, speech development, speaking skills, creativity, interactive methods.

\section{INTRODUCTION}

At present, in the context of globalization and the reform of society, the education of new thinkers requires significant changes in the education system. All-round development of a child is possible only on the basis of mastering the centuries-old experience of mankind due to his interaction with adults, who are the custodians of human experience, knowledge, abilities and culture. This experience can only be conveyed through the most important function of human communication - language. Reforms in the education system and the law on the state language require changes in the formation of children's speech, in particular, in the methodology and practice of speech development in preschool and adult children. 


\section{MATERIALS AND METHODS}

According to the methodological literature, the basis of literary language is mainly monologue. Therefore, the development of speech is important in the education system. Speech is a type of human activity that uses thinking on the basis of language tools (words, phrases, sentences). Speech serves the function of communication and communication, the emotional expression of ideas and the influence of others. Welldeveloped speech serves as one of the important means of one's active activity in society. For the student, speech is a tool for successful learning at school. What is speech development?

If the student and his / her work on the language are considered, then speech development means active practical mastery of the language in all its aspects (pronunciation, vocabulary, syntactic construction). Creating a healthy natural environment in educational institutions, their proper treatment, will increase the desire to talk to others. To do this, it is important to achieve a logical unity of form and content of children's speech, which consists of the following:

- Initially, the child has his own vocabulary;

- Pay attention to the clear formation of the grammatical structure of children's speech;

- Education of sound culture in children;

- Development of dialogic speech;

- To tell a story;

- To acquaint children with fiction.

Children's speech development should be done on the basis of an appropriate program or through various methods. This requires creativity from educators. In the process of developing children's speech, teachers are also required to have a good speech, to be able to pronounce words correctly and to build sentences grammatically correct. The following methods can be used to improve students' speech in the literacy process:

1. Conduct regular discussions and discussions with students on a variety of topics in class or outside of class. The conversation is a dialogical method of education, which requires questioning, expressing one's point of view. The interview is conducted with children gaining some knowledge and experience about things and events. In the process of conversation, children's existing knowledge is identified, enriched, systematized. Children express their ideas and impressions in conversations on various topics. This process requires intelligence from the teacher or educator. Because every child's thoughts and words should be relevant to the content of the conversation and correspond to the norms of literary language.

2. Teach children to draw a story based on a picture. Storytelling is a much more complex process than storytelling. Because children themselves have to choose the content of the story on different pictures, its form of speech, to tell it in sequence. In this process, teachers can use the following methods:

Let's say the teacher shows the students a picture of a parrot.

Then the teacher looks at the picture and asks the following questions:

a) What colour is the parrot?

b) Do parrot feathers look the same everywhere?

c) Put grain, eggs, cottage cheese, carrots, apples in the cage. 
Which one does the parrot eat?

d) Who can write a beautiful story about a parrot?

Children use both their speaking skills and their mental abilities in the process of answering such questions.

3. Enhance speech by telling a story based on a toy or object.

From the earliest stages of a child's life, a toy is a companion and a source of joy. Educator A.S. Makarenko "Material basis" of toy play. The toy is involved in the creation of the game. It manifests itself as a special partner of the child, affects his personality.

\section{This process is as follows:}

Children imagine themselves in a toy store. He asks the seller to give him the name of the toy, indicating the colour, shape and characteristics of the toy. At this time there is a dialogue between the seller and the child.

4. Enhancing speech through various didactic games. In this process, the teacher can play the game as follows. "By definition, I'll find out". In this case, several objects are placed on the table. Students choose a subject and the teacher asks them a question about the subject. For example:

a) What is the shape?

b) What colour?

c) What is it used for?

d) What is it made of?

5. Enhancing children's speech using a variety of interactive methods. In this case, the teacher can use a variety of methods and modern technologies. In the process, educators may ask children to retell the story they have heard by listening to audio tales. At the same time, children develop both speech skills and memory.

The role of the family in the development of children's speech culture is also very important. The uniqueness of the Uzbek family lies in the fact that it strives for the rules of speech etiquette.

If parents diligently inculcate in the child the education, culture of speech, human qualities, he will grow up to be a mature, well-rounded, healthy, independent thinker, and most importantly, a decent person.

\section{CONCLUSION}

One always learns the culture of speech from one's parents. The culture of speech has a special place in the basis of spiritual and moral education of the younger generation. For a child's speech to be well-formed in the family, parents must follow the etiquette of the child's development, pronounce every word correctly and teach the names of each subject correctly.

In short, all the reforms being carried out in the country today are based on the tasks of delivering young people to our society as fullfledged adults, training competitive personnel and gaining a worthy place in the world community. In this process, teachers are required to take on a very complex responsibility.

\section{REFERENCES}


1. D.R. Babayeva. (2018). Theory and methods of speech development. Tashkent.

2. National encyclopedia of Uzbekistan. Toshkent-2005.

3. Hamdamova. M. (2007). Pedagogical and psychological bases of the mechanism of development of the intellectual potential of youth. Tashkent.

4. Qosimova. K, S.Matchonov, $\mathrm{X}$. Gulomova, Sh. Yuldasheva, Sh. Sariev (2009). Methods of teaching the native language. T. "Noshir", 352 p.

5. Ziyaqulova, M. S., \& Hayitova, F. A. (2020). Ways to increase the creativity of pupils in primary education. Academicia: An International Multidisciplinary Research Journal, 10(6), 1332-1335. 